\title{
Arthur Macdonald Allchin - a memoir
}

\author{
By S. A. J. Bradley
}

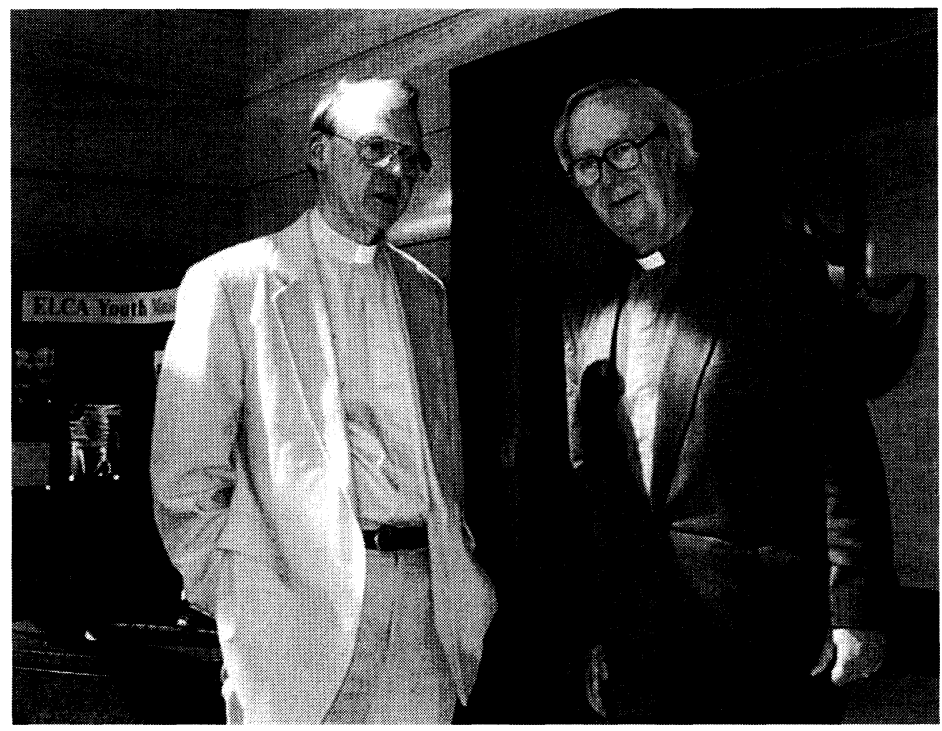

Donald Allchin (right) with Norman A. Hjelm at the Chicago Grundtvig Conference 1995

Donald (formally Arthur Macdonald) Allchin, who died in Oxford on 23 December 2010 at the age of 80 , was one of the outstanding theologians associated with the former Centre for Grundtvig Studies in Aarhus from 1989 and into the new millennium. As a frequently invited visitor to Aarhus he was variously involved, formally and informally, in planning, teaching, supervision and examination, over nearly two decades of the Centre's leading initiative in the domestic and international advance of Grundtvig studies. He was co-editor of two essay-collections, Heritage and Prophecy: Grundtvig and the English Speaking World (1993) and Grundtvig in International Perspective: Studies in the Creativity of Interaction (2000) published under the Centre's imprint, and he contributed papers to those volumes and to Grundtvig-Studier and other learned journals. He also served as a committee member of Grundtvig-Selskabet af 8. september 1947. His insights from nearly half a century of interest in Grundtvig he gathered in his much-praised book - N. F. S. Grundtvig. An Introduction to his Life and Work (1997; hereafter 'Allchin 1997') published both in English and in a distinguished Danish translation by Jakob Balling, as Grundtvigs kristendom: menneskeliv og gudstjeneste (2002). Other important writings include: The Silent Rebellion (1958), 
The Spirit and the Word (1963), The World is a Wedding (1978), The Dynamic of Tradition (1981), The Joy of all Creation (1984), Threshold of Light (1986), The Heart of Compassion (1989), and God's Presence Makes the World (1997).

A charmingly courteous and warm-hearted man, Allchin was also hugely knowledgeable, impressively well-read and blessed with a memory which only in his final illness began to let him down. He was a theologian who discreetly nurtured in his own life the spirituality upon which he was widely esteemed as an illuminating and inspiring writer. He understood and admired such eremitical figures as the Trappist Thomas Merton (whom he visited in America and corresponded with, and whose work he subsequently promoted as president of the Thomas Merton Society of Great Britain and Ireland following its foundation in 1993). Periodically, he himself withdrew into monastic retreats. He was also unworldly, sometimes to the indulgent despair of friends, in the basic management of domestic life. Yet he was always abreast of the political and social issues of the day, at home and abroad, and he was thoroughly gregarious and sociable. The joke was often repeated that if two people from opposite sides of the globe somehow became stranded on the same desert island, the one thing they would discover they had in common was that both of them knew Donald Allchin: his circle of friends, colleagues and acquaintances around the world was indeed prodigiously wide and among them he was held in esteem and affection.

As one who shared counsels with three Archbishops of Canterbury (Ramsey, Runcie and Williams) and various dignitaries of the Eastern Orthodox Church (including Metropolitan Kallistos Ware of Diokleia who, as Timothy Ware, had been a fellow-pupil at Westminster School), Allchin was nevertheless so little concerned with selfpromotion and scholarly flashiness that many who were personally encouraged by his genuinely enthusiastic interest in their work and ambitions knew little of the impressive credentials he could have chosen to parade.

An obituary in The Independent described him as "a freelance theologian with private means but no ambition". Its author then went on to illustrate most amply that, though not pressed by economic necessity to seek formal professional advancement in church or university, Allchin was far from unambitious. His overarching aspiration was (as the same author expressed it) "to foster an awareness of the underlying unity between the major strands of Christianity, throwing new light on our understanding of diverse traditions and belief systems" and in particular to contribute something to repairing the ancient breach between the Orthodox and the Western Christian 
Churches. Most of his publications and his diverse undertakings, including his presidency of the Thomas Merton Society, his service as the first Director of the St Theosevia Centre for Christian Spirituality in Oxford (1987-94) and his long engagement with Grundtvig studies, served in varying ways and degrees this highly idealistic aim.

Certainly academic and ecclesiastical distinctions came his way. After graduating from Christ Church Oxford and Cuddesdon (Theological) College he was appointed (1956-60) curate of St Mary Abbots in Kensington, then (1960-69) a Priest-Librarian of Pusey House in Oxford, a bastion of the Anglo-Catholic tradition in the Church of England. In 1973 he was nominated residentiary Canon of Canterbury Cathedral with responsibility to the Archbishop for ecumenical relations, in particular with the Orthodox communions. Among several honorary doctorates was one bestowed on him by the Bucharest Orthodox Theological Institute in recognition of his services to Orthodox-Anglican relations: his bond with Romania remained strong to the end. Another was conferred by the University of Aarhus, an honour particularly dear to him as a seal upon his long and affectionate attachment to Denmark. From 1992 he held an honorary (but working) Theology professorship in the University of Wales. In 2006 he became one of the distinguished recipients of a Lambeth Doctorate of Divinity - a substantive (not a purely honorary) degree of ancient status, granted by the Archbishop of Canterbury and ranking with the doctorates of Oxford and Cambridge Universities.

His first substantial publication, The Silent Rebellion (1958), already revealed much about the man. It was a sympathetic study of the nineteenth-century resurgence of the monastic ideal among men and women within the Anglican Church. In the Epilogue, assessing the significance of this revival, he suggested it might be seen as an important move in the early stages of women's emancipation. This is a startling idea if one has not first read the whole study with its concern to acknowledge the courage and singleness of purpose of such women as expressed their Christian spirituality in bonding together in communities to serve the disadvantaged and dispossessed in nineteenth-century society. Already in this early work he expressed convictions which, as he later discovered, he shared with the Grundtvig who wrote (Kvinde-Evangeliet, 1842) that a Church devoid of women was as a grove stripped of leaves, and who declared in the same poem: "If Mary be forgotten / where Jesus yet is named / the heart is over-clamoured / by the brain-spun cant of men." [Og naar Maria glemmes, / Hvor Jesus nævnes end, / Da Hjertet overstemmes / Af Hjerne-Spind hos Mænd!]. Some of us would claim that Chapter 14 ('Annunciation') in Allchin 1997, which discusses Grundtvig's 
"teaching on the special role of women in the scheme of salvation" (op. cit., 228) and Grundtvig's convictions concerning "Mary and her place in the Christian faith and life" (ibid., 230) is among the most insightful in this fresh-eyed, subtle and elegantly written study of Grundtvig.

In fact, as early as 1961, in an article in The Eastern Churches Quarterly ('Grundtvig's Translations from the Greek' in Vol. XIV, no. 1, 28-44), acknowledging indebtedness to Jørgen Elbek (Grundtvig og de grceske salmer, 1960), Allchin comments upon "the particular attraction which the feminine element in the Orthodox hymns seems to have had for [Grundtvig]. He is drawn for instance towards the verses about the myrrh-bearing women at the tomb, and attaches special importance to the fact that it was women who first greeted the risen Christ" (41). Though Allchin does not discuss the fact here, this proclamation of the merited favour granted to the women at the tomb also has an eminent place in the tradition of the Western Church. Through Gregory the Great it passes to the great Anglo-Saxon scholar, the Venerable Bede, in his commentary upon the Gospels: $O$ felices feminae! O happy women, he exclaims, who merited (meruerunt) to be those that should reveal to the world Christ's resurrection. For ei quem uiuentem dilexerant etiam mortuo studio humanitatis obsequuntur: "they observed upon the dead one - whom living they loved - the devotion of humanity." Such is their unswerving sense of ministry to their Lord that his death does not shake it; and their merited reward is to announce the Lord's triumph over death itself. Thus Allchin points out Grundtvig's affinity with the patristics of the Eastern Church and opens the way for others to note Grundtvig's affinity with the patristics of the Western.

Allchin understood better than many the realities he and Grundtvig were talking about as regards women and spirituality. He published a number of studies of outstanding women mystics as diverse as the twentieth-century Anglican Evelyn Underhill (d. 1941), the eighteenth-century Welsh Methodist poet Ann Griffiths (d. 1805), and the medieval English mystic Dame Julian of Norwich (d. ca. 1416), comparing them in some cases with continental counterparts. For many years he was Warden of the Community of the Sisters of the Love of God at Fairacres in Oxford and of the Society of the Sacred Cross, a community for women at Tymawr in Wales.

It is no mere coincidence that the surviving writings of Ann Griffiths so admired by Allchin are in the form of poems and hymns, nor that another of his enthusiasms was for the work of the English poet and religious writer, Thomas Traherne (d. 1674) - and for the hymns of Grundtvig. Here too Allchin stood close to Grundtvig in 
having a lively awareness of the condensed, allusive and metaphorical idiom of poetry as being eminently fitted to the purposes of articulating the transcendental; and like Grundtvig he found - and, one might say, brought rejoicing home - abiding continuities in religious poetry, reaching back far beyond the watershed of the Reformation to ancient Greek and Latin texts and to medieval Welsh and Anglo-Saxon poetry. Ecumenism had for him a highly important literary-historical dimension.

His responsiveness to the literary aspects of religious discourse was indeed lively and subtle, whether it was poetry or prose (or something in between, as some of Grundtvig's sermons might seem to be) that lay before him. "Preaching is Grundtvig's theological workshop" he wrote. "In the sermons Grundtvig writes himself into clarity - and to put it briefly, this is the clarity we find in the hymns" (Allchin 1997, 21). Inspired by the work of the Sermons group associated with the Centre under the direction of Christian Thodberg, he was particularly alert to Grundtvig's dual strategy of writing hymns to embody in a different format and genre, and with a sharper clarity, the themes of his sermons. Though duly modest over his ability to catch the nuances of Danish idiom, Allchin nonetheless brought to bear upon his analysis of particular sermons and hymns not only a subtle theological alertness but also a highly developed literary-critical sensibility. Incidentally, it is relevant to record that his own prose translations of hymns discussed in his book inspired the leading English hymn-writer Alan Gaunt to recreate twenty-two of Grundtvig's hymns in English and publish them in his anthology Delight that never dies: Hymns 1997-2003.

Not all his Grundtvigian friends and readers have agreed with the appropriateness of the Anglo-Catholic and the ecumenical standpoints from which Allchin approached his own interpretations and evaluations of Grundtvig. Nor, unsurprisingly, did he, the twentiethcentury Anglo-Catholic, agree with all that he found in Grundtvig the nineteenth-century Lutheran. But he sought the common ground in Christian belief wherever he could find it. He also - in his characteristically undogmatic manner - signposted the way for others to explore. Of Grundtvig's teachings on Mary he wrote: "It is difficult not to think that there is theological material here which will be useful in the future, in the dialogue between Rome and Orthodoxy and the Churches of the Reformation" (Allchin 1997, 241); and, more broadly: "[Grundtvig's] exposition of the Christian faith, his theology, is at once old yet new, necessarily western in its form, yet constantly coloured by insights characteristic of the Christian East. This is a theology of praise and proclamation, a doxological and kerygmatic 
presentation of the faith, with ecumenical implications which need to be explored" (ibid., 6).

Characteristically too, he included all stubbornly dogmatic parties, ancient and modern, at home and abroad, in the reproach to bigotry which he would gently deliver from time to time - as when he wrote of "the old adversarial arguments [...] still commonly used between Catholic and Protestant, as in Northern Ireland. Such arguments are also still in use in the older and no less hardened schism between Christian East and West. They recur in surprising places wherever we are too lazy to discard old and unprofitable habits of mind, at times when we affirm our own position primarily by denying that of others, so that long after we have ceased to believe positively in what is either Catholic or Protestant or Orthodox we know in our hearts that at least we reject the other" (ibid., 225). In this spirit, he followed with close interest the elaborate consultation process whereby the Danish Folkekirke collectively decided, in the early nineteen-nineties, not to sign the Porvoo Declaration. The outcome was a great disappointment to him, as it was to many other friends of Denmark. He no doubt played his informal role in keeping a dialogue open over the following years, but he was too unwell to have any part in the solemnities when, in October 2010, the Danish Folkekirke finally resolved to join the Porvoo Community.

Allchin rather loved the anecdote narrated by Frederik Hammerich of his last conversation with Grundtvig, shortly before Grundtvig's death, as they sat together on a late summer evening in 1872, looking out across the Øresund from Store Tuborg. Their talk centred about an Anglo-Saxon poem, The Ruin, and Allchin was moved by the complex nuances of the story. One of the first conversations I recall having with Allchin was also about an Anglo-Saxon poem, The Dream of the Rood. We were sitting together on an organised coach excursion into ancient Slesvig from Sandbjerg Slot where the Centre for Grundtvig Studies was holding its first international conference in September 1989. Not only did my new acquaintance prove to share my enthusiasm for Rood, as one of the finest devotional and affective poems in the English language, not only did he at once understand my claim that the poet brilliantly used affective theory and method handed down to the Anglo-Saxon Church from Gregory the Great and other Fathers of the western and eastern churches, but he gave me an impromptu tutorial upon the spiritual condition concerned, which I was calling (after the Latin Fathers) compunctio cordis and he preferred to call (after the Greek) penthos. I was then a nervous newcomer to Grundtvig, charged with speaking upon Grundtvig and Anglo-Saxondom. I had already had conversations with such as 
William Michelsen, Anders Pontoppidan Thyssen, Christian Thodberg, Jakob Balling, Jens Holger Schjørring and the young Kim Arne Pedersen. Vagn Wåhlin guided us back into antiquity at the royal mounds at Jelling and the site of the Nydam Boat; and, standing on the ramparts of Dybbøl Banke, Theodor Jørgensen brought some of us close to tears with his narrative of the bombardment of Dybbøl Mølle in 1864. And, amidst all this, in intermittent conversations, Allchin proved to be an Anglo-Saxon soulmate. As all this came together I began to appreciate what a rich project and what a remarkable team which Allchin and Schjørring later liked to label "The Home Team" I was fortunate to have been invited to join. My friendship with Allchin - while it essentially remained part of the fabric of the energetic centre of Grundtvig scholarship in Aarhus - quickly became a personal one sustained, when we were not together upon the Centre's business, by long telephone conversations which always left one feeling recharged with the enthusiasm of Allchin's favourite terms of evaluation: "wonderful!" and "extraordinary!"

The crowded funeral and requiem mass in the Church of St Mary Magdalene in Oxford was presided over by the Archbishop of Canterbury (whose academic supervisor Allchin had once been), assisted by the Orthodox Metropolitan of Diokleia. It was as ecumenical a farewell as Allchin himself could have wished. Quakers were there, Methodists, Jesuits and religious of other orders, women and men, Lutherans and Anglicans, representatives of the Church of Wales, family and friends from various countries of the world.

Donald Allchin, through conference, lecture and seminar participation and through his publications and editorial work contributed to a remarkable season of both planting and harvesting in the Centre for Grundtvig Studies in Aarhus, under the leadership and administration of Thodberg, Schjørring and Kim Arne Pedersen. Not all that was planted came to fruition, nor was the season without its periods of stormy weather; but Allchin's death gives us occasion to review and evaluate what was achieved in the fruitful international and crossdisciplinary vekselvirkning (one of Allchin's favourite words and concepts) - the cross-fertilisation, the interchange - which was facilitated by the benign and creative husbandry fostered there. A rich legacy has been left to successors - of whom great things are expected, indeed required, if the current goodwill and generosity towards Grundtvig studies, owed in no small measure to the spadework of the past two decades, are to be honoured. 